\title{
Report on Temperatures and Open-Air Vegetation at the Royal Botanic Garden, Edinburgh, from November 1881 till July 1882. Compiled from Notes read at Meetings of the Society
}

John Sadler Curator F.R.Ph.S.

To cite this article: John Sadler Curator F.R.Ph.S. (1883) Report on Temperatures and OpenAir Vegetation at the Royal Botanic Garden, Edinburgh, from November 1881 till July 1882. Compiled from Notes read at Meetings of the Society, Transactions of the Botanical Society of Edinburgh, 14:1-4, 371-374, DOI: 10.1080/03746608309468428

To link to this article: http://dx.doi.org/10.1080/03746608309468428

曲 Published online: 01 Dec 2010.

Submit your article to this journal ए

Џll Article views: 3

Q View related articles $\sqsubset$ 
peculiar structure of the calyx; but the leaflets are not coriaceous, the pedicles longer, the calyces twice as long, thus reaching much higher up to the corolla, and the teeth of the column are neither rounded nor retuse-truncate; the fruits are likely also different.

This noble and singular tree is dedicated to Dr. Rudolph Schiffner of Vienna, who for many years has been the president of the great and highly scientific Pharmaceutical Society of Austria.

Report on Temperatures and Open-Air Vegetation at the Royal Botanic Garden, Edinburgh, from November 1881 till July 1882. Compiled from Notes read at Meetings of the Society. By the late JoHn SADLER, F.R.Ph.S., Curator.

The forest trees and shrubs flowered remarkably well during the early summer of 1881, and most of them produced fruit. The garden suffered very little from the great storm of October 1881.

In November 1881 the thermometer was seven times at or below $32^{\circ}$. On two occasions it stood at $25^{\circ}$. The dates of these low temperatures were the 1 st, $2 \mathrm{nd}, 4 \mathrm{th}, 8 \mathrm{th}, 18 \mathrm{th}$, and 26 th.

Upwards of thirty species and varieties of plants were in full flower in the rock garden; Christmas roses blooming for two or three weeks.

In December the thermometer was at or below the freezing-point on sixteen occasions. The greatest frost was on the $22 \mathrm{nd}$ and $23 \mathrm{rd}$, when $26^{\circ}$ and $23^{\circ}$ were respectively registered. These were relatively high readings, when compared with the same month, as well as that of November 1880.

In January 1882 the thermometer fell below the freezingpoint on six occasions, as compared with twenty-seven occasions in January 1881 . On the 4 th and on the 29 th, $28^{\circ}$ and $26^{\circ}$ were respectively registered.

In the rock garden fifty-two species and varieties of plants had flowered, including fourteen species of Hellebore, as well as mignonette, besides crocuses, pansies, and roses. 
In February the thermometer was at or below the freezing-point on eight occasions, as against twenty in 1881. The lowest readings for the month were-1st, $32^{\circ}$; 2nd, $29^{\circ} ; 3$ rd, $30^{\circ} ; 7$ th, $28^{\circ} ; 9$ th, $29^{\circ} ; 16$ th, $29^{\circ} ; 19$ th, $30^{\circ} ; 28$ th, $32^{\circ}$. The three highest morning readings (9 A.M.) were on the 8 th and 9 th $\left(48^{\circ}\right.$ and $51^{\circ}$ respectively).

Forty-seven species and varieties of plants came into flower in the rock garden, amongst them were Galanthus plicatus, G. Elwesii, Crocus biflorus, C. etruscus, C. imyerati, Leucojum vernum, Bulbocodium vernum, \&c. There also flowered Helleborus colchicus, white and blue Hepaticas, the Botanic Garden purple variety of the common primrose, as well as yews, and certain species of Alnus, hazel, \&c.

In March the thermometer was at or below the freezingpoint on seven different occasions. The dates were as follows:-1st, $32^{\circ} ; 7$ th, $30^{\circ} ; 21$ st, $31^{\circ} ; 22 \mathrm{nd}, 30^{\circ} ; 23 \mathrm{rd}$, $29^{\circ}$; 25 th, $32^{\circ}$; and 26 th, $32^{\circ}$.

Vegetation was six weeks in advance on the 9 th inst. of what it was at the same period in 1881 in the rock garden; and specimens of the following plants in flower were exhibited at the March meeting of the Botanical Society.

Sisyrinchium grandiflorum

(white and purple).

Iris reticulata.

Helleborus foetidus.

$\begin{array}{ll}, & \text { angustifolius. } \\ , & \text { guttatus. } \\ , & \text { orientalis. } \\ , & \text { purpurascens minor. } \\ " & \text { viridis. } \\ , & \text { olympicus albus. } \\ , & \text { colchicus. }\end{array}$

Hepatica angulosa.

Daphne Mezereum.

Draba aizoon.

" aizoides.

Dentaria enneaphylla.

Aubrietia purpurea.

$$
\begin{aligned}
, & \text { grandiflora. } \\
, & \text { colestis. } \\
, & \text { Hendersoni. }
\end{aligned}
$$

Viola species, yellow variety.

Lithospermum prostratum.

Andromeda calyculata latifolia.

$$
\text { , media. }
$$

Omphalodes verna.

Arabis procurrens.

" albida.

Thlaspi prostrata.

Symplocarpus fotidus.

Anemone coronaria.

, fulgens.

Primula denticulata.

$" \quad$ dark variety.

" intermedia.

Saxifraga crassifolia.

" rubra.

" media.

Primula marginata.

, vulgaris.

" , (single white). 
Primula vulgaris (double white).

Coryclalis cava.

" bulbosa rubra.

Polygala Chaurehuxus.

Erica herbater.

" carnea alba.

liandragora vernalis.

Iberis petræa.

Dondia epipactis.

Soldanella montana.

Vinca minor.

Saxifraga oppositifolia.

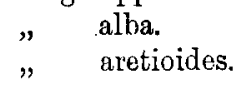

Erythronium dens canis.

" grandiflorum.

Cyclamen Coum vernum.

Corbularia sp. (Maw).

Orrithogalum sp. (Maw).

Gagea lutea.

Scilla sibirica.

" præcox.

", bifolia.

$" \quad$, taurica.

" " rubra.

" " alba.

Puschkinia scilloides.

Bulbocodium vernum.

In April the thermometer was at or below the freezingpoint on six occasions; it had been on twenty-one during the same month last year. The lowest temperatures were on the following dates:-8th, $32^{\circ} ; 10$ th, $27^{\circ} ; 12$ th, $29^{\circ}$; 13 th, $31^{\circ}$; 16 th, $26^{\circ} ; 27$ th, $28^{\circ}$. The frosts of this month, owing to the advanced condition of vegetation, did much injury to fruit trees and bushes in flower, as well as to tender shoots in many parts of the country.

During this month 231 species and varieties of plants came into flower in the rock garden, as compared with 52 in April last year.

In the early part of May, though the thermometer did not fall to the freezing-point, yet the night temperatures were very low, as shown by the following readings:-1st, $34^{\circ}$; 2nd, $39^{\circ}$; 3rd, $35^{\circ}$; 6 th, $34^{\circ}$; 7 th, $36^{\circ} ; 8$ th, $33^{\circ} ; 9$ th, $34^{\circ} ; 10 \mathrm{th}, 35^{\circ}$. On the $4 \mathrm{th}, 5 \mathrm{th}$, and 11 th the thermometer registered $43^{\circ}$.

On the 11 th of the month 346 species and varieties were in flower on the rock garden, as compared with 158 at the same date last year.

June 1882.- The lowest readings of the thermometer during the month were on the 1 st, $41^{\circ} ; 2$ nd, $41^{\circ} ; 11$ th, $37^{\circ}$; 12 th, $38^{\circ} ; 16$ th, $35^{\circ} ; 17$ th, $35^{\circ}$.

Since the last month 173 species and varieties of plants came into flower in the rock garden, making a total of 666 for the season, as compared with 484 at the corresponding date last year (1881). Amongst them were the following :- 
Aster graminifolius.

Anthericum liliago.

Cathcartia villosa.

Campanula thyrsoidea.

Cypripedium spectabile.

Dianthus alpinus.

" suavis.

Eriogonum aureum.

Gentiana lutea.

Gorteria acaulis.

Gillenia trifoliata.

Kalmia angustifolia.

Lilium Chaixii.

" colchieun.

Linuæa borealis.

Lonicera tomentella.

Milla lougipes.

Orchis foliosa.

„ maculata superba.

Papaver alpina.

Primula capitata.

Spiræa aruncus.

Stenactis speciosa.

Wulfenia Amherstiana.

July.-The lowest readings of the thermometer during the month were registered on the mornings of the 5 th, $44^{\circ}$; 9 th, $45^{\circ} ; 11$ th, $44^{\circ} ; 12$ th, $45^{\circ} ; 25$ th, $46^{\circ} ; 26$ th, $45^{\circ}$. Since last month 135 species and varieties of plants came into flower in the rock garden, making a total of 801 compared with 561 at the corresponding period of last year. The following were amongst those which came into flower during the month:-

Alstrœmeria aurea.

Baptisia australis.

Cassinia fulvida.

Convolvulus lineatus.

Delphinium velutinum.

Dianthus cruentus.

Erica ramulosa.

Gaillardia grandiflora.

Gentiana septemfida.
Hypericum empetrifolium.

Lilium pardalinum.

Mchringia muscosa.

Potentilla formosa.

Senecio pulcher.

Lilium auratum.

, dalmaticum.

Mulgedium alpinum.

Olearia Haastii.

Note on Table of Flowering of Plants in the Royal Botanic Garden, Edinburgh, from 1850 to 1882 . Вy ЈоHN SAdLer, Curator. (With Table).

(Exhibited 13th July 1882.)

The annexed table shows the dates of the flowering of forty plants during three decades and two years. The observations were begun by the late James Macnab, and continued by his successor. 